DOI: 10.17951/lrp.2018.37.3.93-106

\author{
JANUSZ KiRENKO \\ Uniwersytet Marii Curie-Skłodowskiej w Lublinie \\ https://orcid.org/0000-0002-6525-4007 \\ EWA SiENKIEWICZ \\ Uniwersytet Medyczny Lublin \\ https://orcid.org/0000-0003-1122-9786 \\ Jolanta SzymańsKa \\ Uniwersytet Medyczny Lublin \\ https://orcid.org/0000-0002-9917-2907
}

\author{
AnNa Malm \\ Uniwersytet Medyczny Katedra i Zakład Mikrobiologii Farmaceutycznej \\ z Pracownią Diagnostyki Mikrobiologicznej Lublin \\ https://orcid.org/0000-0003-1503-7634
}

\title{
SOCJODEMOGRAFICZNE UWARUNKOWANIA SPOSOBÓW RADZENIA SOBIE W SYTUACJACH TRUDNYCH PRZEZ PERSONEL PIELEGGNIARSKI
}

Streszczenie: Rezultaty radzenia sobie w sytuacjach problemowych można ocenić, analizując reakcje fizjologiczne, czynności motoryczne i objawy emocjonalne. Im efektywniej człowiek radzi sobie w sytuacji problemowej, tym lepsze jest jego funkcjonowanie psychospołeczne. Adekwatność wybranego profilu radzenia sobie wpływa na stan zdrowia somatycznego i psychicznego. Najistotniejszą cechą radzenia sobie powinna być elastyczność - dopasowanie do zmieniających się warunków. Celem badań była ocena socjodemograficznych czynników warunkujących radzenie sobie w sytuacjach trudnych przez personel pielęgniarski. Badaniami objęto 81-osobową grupę pielęgniarek i pielęgniarzy. Wykorzystano autorską metryczkę dotyczącą socjodemograficznej charakterystyki badanych osób oraz Kwestionariusz radzenia sobie z problemami (WCQ Lazarus i Folkman). Na podstawie wyników badań stwierdzono, że istnieje zależność pomiędzy radzeniem sobie w sytuacjach trudnych przez personel pielęgniarski a miejscem zamieszkania, wiekiem i stażem pracy w zawodzie. Poszczególne strategie radzenia sobie w sytuacjach trudnych badanych osób nie korelują z płcią i wykształceniem. 
Badani najczęściej wybierają profil radzenia sobie określany jako nastawienie pozytywne. Koncentracja na problemie oraz nastawienie pozytywne w największym stopniu oddziałują na psychospołeczne funkcjonowanie badanych. Umiejętności radzenia sobie z problemami w sytuacjach trudnych przez personel pielęgniarski są częściowo uwarunkowane socjodemograficznie. Duże znaczenie mają posiadane zdolności interpersonalne w zakresie komunikacji społecznej oraz zasoby odpornościowe. Należy rozszerzyć badania o determinanty dyspozycji osobowościowych personelu pielęgniarskiego w celu określenia ich wewnątrzosobowych zasobów psychospołecznych - poczucia koherencji, samooceny oraz wsparcia społecznego. Uzyskane informacje o predyspozycjach zawodowych mogą być przydatne w kształceniu i doskonaleniu zawodowym personelu pielęgniarskiego.

Słowa kluczowe: personel pielęgniarski, sytuacje problemowe, stres, radzenie sobie

\section{WSTEP}

Personel pielęgniarski pracujący w ochronie zdrowia posiada wymagane kwalifikacje potwierdzone odpowiednimi dokumentami. Zgodnie ze specyfiką zawodu, podejmuje działania z zakresu promocji zdrowia, profilaktyki chorób, świadczeń pielęgnacyjnych, leczniczych, diagnostycznych, usprawniających i rehabilitacyjnych (Frąckowiak 2010, s. 53-70). Wszystkie czynności wobec pacjenta lub podopiecznego opierają się na określonych regulacjach prawnych i sprawdzonych standardach postępowania. Organizacja pracy: ustalanie celów, potrzeb, sposobów i zakresu pomocy, a także niezbędnych środków do działania, wymaga od personelu pielęgniarskiego profesjonalnej wiedzy, a świadomość działań i odpowiedzialności za życie i zdrowie pacjenta lub podopiecznego są źródłem wielu sytuacji trudnych. Osoby pracujące w zawodzie narażone są na wiele czynników, które mogą wpływać negatywnie na zdrowie, a różnorodność wynika ze zróżnicowanych uwarunkowań wykonywanego zawodu (Wrońska, Krajewska-Kułak 2007). Ryzyko kontaktu z czynnikami szkodliwymi stanowi nie tylko obciążenie osoby pracującej, ale może mieć wpływ na wzrost zdarzeń niepożądanych, jest również przyczyną stresu i zaburzeń zdrowia somatycznego i psychicznego (Kuriata i in. 2011). Personel pielęgniarski jest narażony na szkodliwe czynniki:

- biologiczne, np. gruźlica, HIV/AIDS, SARS;

- ergonomiczne (dźwiganie ciężarów);

- chemiczne (glutaraldehyd, tlenek etylenu);

- fizyczne (promieniowanie, potknięcia, upadki);

- psychospołeczne (stres, agresja, przemoc) (Kowalczuk i in. 2008, s. 211-215).

Według „Prevention and Control of Nosocomial Infections” z 1997, patogeny przenoszone przez krew i płyny ustrojowe stanowią zagrożenie dla 63\% pielęgniarek 
w codziennej pracy (Kowalczuk i in. 2008, s. 211-215). W badaniach Perek (Perek, Kózka, Twarduś 2007, s. 223-228) wykazano, że 3/4 respondentek za stresujące uznało zagrożenie bezpieczeństwa osobistego z powodu możliwości zakażeń HIV, WZW typu B i C, cytomegalią oraz innymi chorobami zakaźnymi. W badaniach dotyczących zagrożeń w pracy pielęgniarek środowiskowych Frąckowiak (2010) wskazała, że najistotniejszą grupą szkodliwych czynników zawodowych są czynniki biologiczne (42\%). Wśród chorób zawodowych większość wskazywała na zakażenie grzybicą (85\%), gruźlicą (79\%), a następnej kolejności wymieniano WZW typu B lub C (70\%).

Ze względu na interdyscyplinarny charakter, współczesne pielęgniarstwo wymaga działań, które łączą wiedzę, umiejętności i doświadczenia profesjonalistów z różnych dziedzin (Bielawska 2014, s. 18-19). Stanowi to nie tylko wyzwanie zawodowe, ale również jest źródłem problemów, m.in. konfliktów interpersonalnych w miejscu pracy, braku umiejętności otwartego komunikowania się i współpracy w zespole oraz nieznajomości oczekiwań członków zespołu (Gaweł 2003, s. 77-82). Nagromadzenie sytuacji problemowych i brak umiejętności radzenia sobie mogą prowadzić do wystąpienia długotrwającej reakcji stresowej, a w konsekwencji do zespołu wypalenia zawodowego (Sęk 2005, s. 93-98).

Niezbędne jest wypracowanie przez personel pielęgniarski efektywnych sposobów radzenia sobie ze stresem i problemami dnia codziennego. Jest to możliwe poprzez umiejętne wykorzystanie posiadanych psychospołecznych zasobów pozostających $\mathrm{w}$ dyspozycji jednostki oraz zewnętrznych - w miejscu zamieszkania i pracy zawodowej.

Celem badań była ocena związku pomiędzy wybranymi czynnikami socjodemograficznymi a wybranymi sposobami radzenia sobie w sytuacjach trudnych przez personel pielęgniarski.

Zmienną zależną stanowiły sposoby radzenia sobie w sytuacjach trudnych, natomiast zmiennymi niezależnymi - czynniki socjodemograficzne: wiek, płeć, miejsce zamieszkania, wykształcenie i staż pracy.

\section{MATERIAŁ I METODY}

\section{OSOBY BADANE}

Przebadano 81 pielęgniarek i pielęgniarzy pracujących na oddziałach: chirurgicznourazowym i położniczo-noworodkowym szpitala miejskiego oraz w przychodni lekarza rodzinnego, w tym 72 kobiety $(88,89 \%)$ i 9 mężczyzn (11,11\%). Największą 
grupę stanowiły osoby w wieku od 30. do 40. roku życia - 37 osób (45,68\%), powyżej 40. roku życia było 29 osób $(35,80 \%)$, a poniżej 30. roku życia - 15 osób (18,52\%). Miejscem zamieszkania dla 53 osób badanych $(65,43 \%)$ było miasto, a 28 osób (34,57\%) mieszkało na wsi. Wykształcenie wyższe posiadało 18 osób $(22,22 \%)$, natomiast 63 osoby badane $(77,78 \%)$ - średnie zawodowe. W badanej grupie przeważały osoby, których staż pracy wynosił od 10 do 20 lat - 33 osoby (40,74\%), więcej niż 20 lat pracy - 26 osób (32,10\%), a 22 osoby (27,16\%) pracowały krócej niż 10 lat.

\section{WYNIKI}

Wskaźnikami zmiennej zależnej były kategorie Kwestionariusza radzenia sobie z problemami (WCQ) Lazarusa i Folkman: Rozwiązanie problemów (RP), Pragnienia (PG), Obiektywizm (OB), Szukanie wsparcia (SW), Nastawienie pozytywne (NP), Obwinianie siebie (OS), Redukowanie napięcia (RN), Zamknięcie w sobie (ZA). Porównano je za pomocą testu to dla par niezależnych w obrębie trzech zmiennych socjodemograficznych: płci, miejsca zamieszkania i poziomu wykształcenia, natomiast w sytuacji porównań pomiędzy więcej niż dwoma grupami zastosowano analizę wariancji jednowymiarowej (ANOVA). Gdy wartość $\mathrm{F}^{\circ}$ przekraczała wartość progową, korzystano z testu NIR badającego istotność różnic między parami średnich dla grup osób z obszaru wieku życia i stażu pracy.

Tabela 1. Zależność zmiennych socjodemograficznych: radzenie sobie wiek badanych osób

\begin{tabular}{|c|c|c|}
\hline & $\mathbf{F}$ & $\mathbf{p}$ \\
\hline RP & 4,175 & $0,019^{*}$ \\
\hline PG & 1,952 & 0,149 \\
\hline OB & 1,659 & 0,197 \\
\hline SW & 3,194 & $0,046^{*}$ \\
\hline NP & 2,824 & 0,065 \\
\hline OS & 0,365 & 0,696 \\
\hline RN & 1,422 & 0,247 \\
\hline ZA & 0,222 & 0,801 \\
\hline
\end{tabular}

$\mathrm{p}$ - istotność statystyczna, ${ }^{\star} \mathrm{p}<0,05$ - poziom istotności statystycznej, $\mathrm{F}$ - współczynnik testu, RP - Rozwiązywanie problemów, PG - Pragnienia, O - Obiektywizm, SW - Szukanie wsparcia, NP - Nastawienie pozytywne, OS - Obwinianie siebie, RN - Redukowanie napięcia, ZA - Zamknięcie w sobie Źródło: opracowanie własne 
Istotne statystycznie zróżnicowanie poziomów: Rozwiązywanie problemu $(\mathrm{p}=$ 0,019) oraz Szukanie wsparcia ( $\mathrm{p}=0,046)$ w odniesieniu do wieku badanych osób oznacza, że istnieje związek pomiędzy ich wiekiem, a wskazanymi sposobami radzenia sobie w sytuacjach trudnych. W grupie najmłodszych osób ważne jest skoncentrowanie się na rozwiązywaniu problemu. Oceniając istotę zagrożenia, określają one plan działania celem jego zmniejszenia albo skutecznej eliminacji, a konfrontację $\mathrm{z}$ sytuacją trudną traktują jako wyzwanie warte wysiłku i osobistego zaangażowania (tabela 1). Grupa badanych w wieku powyżej 40. roku życia kieruje się nie tylko doświadczeniem, ale i rutyną, traktując problem jako kolejne zadanie do rozwiązania. Wiek - jako siła sprawcza i decyzyjna w wyborze i nasileniu sposobu radzenia sobie - wskazuje również na pokoleniową rozbieżność w percepcji siebie oraz postawy wobec sytuacji i innych osób. Szukanie wsparcia to sposób radzenia sobie, który charakteryzuje badane osoby jako poszukujące wsparcia u innych osób, kontaktów, rozmów, rad i akceptacji. Wymiana doświadczeń i poglądów - zarówno w środowisku zawodowym, jak i rodzinnym - stanowi cenne źródło w radzeniu sobie z problemami. Uzyskany wynik wskazuje na otwartość najmłodszych osób na doświadczenie starszych kolegów oraz dobrą umiejętność komunikacji w zespole.

Tabela 2.Zależność zmiennych socjodemograficznych: radzenie sobie badanych osób

\begin{tabular}{|c|c|c|c|c|c|c|c|c|c|}
\hline & $\mathbf{K}$ & $\mathbf{M}$ & $\mathbf{t}$ & $\mathbf{d f}$ & $\mathbf{p}$ & $\mathbf{N}-\mathbf{K}$ & $\mathbf{N}-\mathbf{M}$ & $\mathbf{S D}-\mathbf{K}$ & $\mathbf{S D}-\mathbf{M}$ \\
\hline RP & 18,86 & 17,78 & 0,517 & 79 & 0,607 & 72 & 9 & 5,99 & 5,38 \\
\hline PG & 8,26 & 6,22 & 1,509 & 79 & 0,135 & 72 & 9 & 3,79 & 4,12 \\
\hline OB & 8,18 & 6,33 & 1,592 & 79 & 0,115 & 72 & 9 & 3,28 & 3,28 \\
\hline SW & 10,67 & 9,22 & 1,015 & 79 & 0,313 & 72 & 9 & 4,00 & 4,21 \\
\hline NP & 6,69 & 5,33 & 1,358 & 79 & 0,178 & 72 & 9 & 2,89 & 2,29 \\
\hline OS & 4,44 & 4,33 & 0,158 & 79 & 0,875 & 72 & 9 & 2,03 & 1,50 \\
\hline RN & 2,18 & 2,22 & $-0,058$ & 79 & 0,954 & 72 & 9 & 2,11 & 1,30 \\
\hline ZA & 3,97 & 3,67 & 0,445 & 79 & 0,658 & 72 & 9 & 1,96 & 1,80 \\
\hline
\end{tabular}

$\mathrm{t}$ - test t-Studenta, df - stopnie swobody, N - liczebność próby, SD - odchylenie standardowe, $\mathrm{p}<0,05$ - poziom istotności statystycznej, $\mathrm{K}$ - kobiety, $\mathrm{M}$ - mężczyźni. Inne skróty jak w tabeli 1

Źródło: opracowanie własne

Z uzyskanych danych wynika, że płeć nie różnicuje w sposób istotny statystycznie sposobów radzenia sobie w sytuacjach trudnych u badanych osób (tabela 2). Kobiety pracujące w zawodzie pielęgniarskim ujawniają tendencję do nieco wyższego poziom radzenia sobie niemal we wszystkich analizowanych strategiach oprócz redukowania napięcia, które jest silniejsze u mężczyzn pracujących w tym zawodzie. 
Tabela 3. Zależność zmiennych socjodemograficznych: radzenie sobie miejsce zamieszkania badanych osób

\begin{tabular}{|c|c|c|c|c|c|c|c|c|c|}
\hline & $\mathbf{M}$ & $\mathbf{W}$ & $\mathbf{t}$ & $\mathbf{d f}$ & $\mathbf{p}$ & $\mathbf{N}-\mathbf{M}$ & $\mathbf{N}-\mathbf{W}$ & $\mathbf{S D}-\mathbf{M}$ & $\mathbf{S D}-\mathbf{W}$ \\
\hline RP & 19,49 & 17,32 & 1,588 & 79 & 0,116 & 53 & 28 & 5,77 & 5,99 \\
\hline PG & 8,06 & 8,00 & 0,062 & 79 & 0,950 & 53 & 28 & 3,64 & 4,31 \\
\hline OB & 8,64 & 6,71 & 2,576 & 79 & $0,012^{*}$ & 53 & 28 & 3,16 & 3,29 \\
\hline SW & 10,87 & 9,82 & 1,114 & 79 & 0,268 & 53 & 28 & 4,06 & 3,94 \\
\hline NP & 7,15 & 5,39 & 2,746 & 79 & $0,007^{\star}$ & 53 & 28 & 2,73 & 2,77 \\
\hline OS & 4,57 & 4,18 & 0,838 & 79 & 0,404 & 53 & 28 & 1,82 & 2,25 \\
\hline RN & 2,32 & 1,93 & 0,825 & 79 & 0,412 & 53 & 28 & 2,16 & 1,76 \\
\hline ZA & 3,98 & 3,86 & 0,273 & 79 & 0,786 & 53 & 28 & 1,96 & 1,92 \\
\hline
\end{tabular}

$\mathrm{M}$ - miasto, $\mathrm{W}$ - wieś. Inne skróty jak w tabeli 1 i 2

Źródło: opracowanie własne

Miejsce zamieszkania różnicuje poziomy Nastawienia pozytywnego i Obiektywizmu (tabela 3). Osoby badane mieszkające w miastach cechuje pozytywny stosunek do rzeczywistości. Są one pełne nadziei i optymizmu, wierzą w pozytywne zakończenie trudnych spraw. Wynika to z przekonania, że wewnątrzosobowe zasoby tkwiące w nich samych i zasoby, które są dostępne w środowisku zewnętrznym sprawią, że będą w stanie poradzić sobie w sytuacjach trudnych. Miasto dysponuje większymi i bardziej dostępnymi możliwościami w sferze infrastruktury, informacji, pomocy i wsparcia niż wieś.

Tabela 4. Zależność zmiennych socjodemograficznych: radzenie sobie wykształcenie badanych osób

\begin{tabular}{|c|c|c|c|c|c|c|c|c|c|}
\hline & $\mathbf{a}$ & $\mathbf{b}$ & $\mathbf{t}$ & $\mathbf{d f}$ & $\mathbf{p}$ & $\mathbf{N}-\mathbf{a}$ & $\mathbf{N}-\mathbf{b}$ & $\mathbf{S D}-\mathbf{a}$ & SD - b \\
\hline RP & 19,89 & 18,41 & 0,935 & 79 & 0,353 & 18 & 63 & 5,54 & 6,00 \\
\hline PG & 7,83 & 8,10 & $-0,252$ & 79 & 0,801 & 18 & 63 & 3,22 & 4,04 \\
\hline OB & 8,06 & 7,95 & 0,116 & 79 & 0,908 & 18 & 63 & 2,78 & 3,47 \\
\hline SW & 11,39 & 10,25 & 1,056 & 79 & 0,294 & 18 & 63 & 4,02 & 4,02 \\
\hline NP & 7,00 & 6,41 & 0,769 & 79 & 0,444 & 18 & 63 & 2,74 & 2,89 \\
\hline OS & 4,44 & 4,43 & 0,030 & 79 & 0,976 & 18 & 63 & 1,76 & 2,05 \\
\hline RN & 2,61 & 2,06 & 1,009 & 79 & 0,316 & 18 & 63 & 2,03 & 2,03 \\
\hline ZA & 4,33 & 3,83 & 0,983 & 79 & 0,328 & 18 & 63 & 1,61 & 2,01 \\
\hline
\end{tabular}

* - p $<0,05$ - poziom istotności statystycznej, a - wykształcenie wyższe, b - wykształcenie średnie zawodowe. Inne skróty jak w tabeli 1 i 2

Źródło: opracowanie własne 
Nie ma związku pomiędzy poziomem wykształcenia badanych osób a radzeniem sobie w sytuacjach trudnych (tabela 4). Osoby z wykształceniem wyższym na 7 spośród 8 strategii radzenia sobie ujawniają co prawda wyższy poziom niż osoby z wykształceniem średnim zawodowym, ale ma to wyłącznie charakter tendencji - podobnie jak w przypadku strategii Pragnienia.

Tabela 5. Zależność zmiennych socjodemograficznych: radzenie sobie staż pracy badanych osób

\begin{tabular}{|c|c|c|}
\hline & F & p \\
\hline RP & 3,154 & $0,048^{*}$ \\
\hline PG & 3,287 & $0,043^{*}$ \\
\hline OB & 3,092 & 0,051 \\
\hline SW & 1,664 & 0,196 \\
\hline NP & 3,535 & $0,034^{*}$ \\
\hline OS & 1,358 & 0,263 \\
\hline RN & 0,739 & 0,481 \\
\hline ZA & 0,501 & 0,608 \\
\hline
\end{tabular}

Skróty jak w tabeli 1

Źródło: opracowanie własne

Analiza danych w odniesieniu do zmiennej niezależnej: staż pracy wskazuje, że istnieje w jej obrębie zróżnicowanie poziomów w następujących strategiach radzenia sobie: Rozwiązywanie problemów, Pragnienia i Nastawienie pozytywne. Schematy postępowania w sytuacjach trudnych wypracowane przez osoby badane w ciągu długiego stażu pracy są zbliżone do zachowań radzenia sobie u osób z krótszym stażem pracy w zawodzie (tabela 5). Osoby z wyższym wykształceniem mają lepsze przygotowanie zawodowe i zajmują stanowiska kierownicze. Jest to efekt zmian w systemie kształcenia pielęgniarek, które skutkowały likwidacją średnich szkół medycznych na korzyść kształcenia na poziomie wyższych studiów licencjackich i magisterskich. Można przypuszczać, że za przyjmowanie postawy wobec sytuacji trudnych, odpowiedzialne są nie tylko różnice międzypokoleniowe, ale również system kształcenia. Uzyskane wyniki w skali Pragnienia wskazują, że osoby w znacznej mierze uciekają od rzeczywistości. Przyjmują postawę pasywną wobec sytuacji trudnych i nie podejmują konkretnych działań w celu zmiany sytuacji. Jest to prawdopodobnie grupa osób zagrożona z powodu wypalenia zawodowego. 


\section{ZAKOŃCZENIE}

Radzenie sobie to podstawowy proces adaptacyjny każdej jednostki. Obejmuje: radzenie sobie jako proces, strategia i styl. Proces radzenia sobie to „stale zmieniające się poznawcze i behawioralne wysiłki, mające na celu opanowanie określonych zewnętrznych i wewnętrznych wymagań, ocenianych przez osobę jako obciążające lub przekraczające jej zasoby" (Strelau 2000). Problematyką stylu radzenia sobie ze stresem zajmowało się wielu autorów, m.in. Carver, Scheier i Weintraub, Folkman i Lazarus, Miller oraz Endler i Parker (Strelau 2000). Carver, Scheier i Weintraub jako pierwsi dokonali rozróżnienia pomiędzy strategią i stylem radzenia sobie ze stresem. Strategię traktowali jako sytuacyjne, a styl jako dyspozycyjne radzenie sobie. Miller natomiast opracowała koncepcję dwóch stylów radzenia sobie. Pierwszy styl to koncentracja uwagi na stresorze i (lub) własnej reakcji, poszukiwanie informacji o sytuacji stresowej i dążenie do konfrontacji z tą sytuacją. Drugi - to styl „unikowy”, polegający na odwracaniu uwagi od stresora i od własnych reakcji, na pomijaniu, odrzucaniu, wypieraniu i zaprzeczaniu informacjom o wydarzeniu stresowym. Zdaniem Lazarusa radzenie sobie ze stresem to aktywność jednostki (proces), która dąży do zmiany transakcji stresowej (Juczyński, Ogińska-Bulik 2008). Aktywność jednostki ma decydujące znaczenie w identyfikacji sytuacji stresowej i jej konsekwencjach. Radzenie sobie ze stresem określa jako „stale zmieniające się poznawcze i behawioralne wysiłki mające na celu uporanie się z określonymi zewnętrznymi lub wewnętrznymi wymaganiami, ocenianymi przez osobę jako obciążające lub przekraczające jej zasoby" (Lazarus, Folkman 1984). Zdaniem Lazarusa i Folkman radzenie sobie ze stresem pełni dwie istotne funkcje: instrumentalną i regulacyjną. Funkcja instrumentalna dotyczy zlikwidowania lub zmniejszenia stresu, natomiast regulacyjna to zachowania, które mają na celu kontrolę emocjonalnych reakcji na sytuacje zagrażające.

O sposobach i przebiegu procesu radzenia sobie ze stresem w sytuacjach trudnych i zagrażających decyduje ogólna dyspozycja osobowościowa, którą posiada każda jednostka (Juczyński, Ogińska-Bulik 2008). W trudnych sytuacjach problemowych wpływających na zagrożenie własnego ,ja”, utratę wartości i dążeń, pozytywne psychospołeczne funkcjonowanie jest możliwe tylko u tych osób, które zgodnie ze swoimi predyspozycjami osobowymi potrafią radzić sobie z problemami. Nie poddają się losowi, traktują sytuację trudną jako wyzwanie dla siebie, pobudzając własną, sprawczą aktywność w celu pokonania problemu. Badane osoby podjęły w większości wyzwanie w celu usunięcia problemu. Można sugerować, że mają przekonanie, że podjęte działania są warte wysiłku i osobistego zaangażowania. Zrozumienie istoty sytuacji problemowych, ocena własnych dyspozycji i dostępność zasobów tkwiących w środowisku skłaniają do 
podjęcia efektywnych sposobów radzenia sobie. Ma to istotne znaczenie, ponieważ powszechnie obserwuje się rosnące występowanie problemów zdrowotnych wśród pielęgniarek (Marcysiak, Dąbrowska, Marcysiak 2014, s. 312-318), co uzasadnia potrzebę badania uwarunkowań radzenia sobie, wynikających nie tylko ze specyfiki warunków pracy, ale również z takiego, a nie innego wpływu czynników socjodemograficznych.

Zawód pielęgniarki wiąże się z koniecznością posiadania umiejętności komunikowania się z pacjentem i jego rodziną, w tym zdolności empatycznych. Wysoki poziom empatii u pielęgniarek wykazano w badaniach Kurowskiej i ZuzaWitkowskiej (Kurowska, Zuza-Witkowska 2011, s. 277-282). Natomiast badania przeprowadzone przez Buyuk i wsp. (2015) w grupie pielęgniarek oddziałów onkologicznych wskazują na większe trudności w komunikacji wśród badanych o wyższym poziomie zdolności empatycznych. Zdaniem Kato (2014) konstruktywne sposoby radzenia sobie w sytuacjach trudnych poprzez aktywny wysiłek w celu polepszenia relacji międzyludzkich, które są przyczyną stresu, mogą powodować obniżenie poziomu stresu psychicznego. $\mathrm{W}$ dążeniu do zachowania równowagi psychicznej bardzo ważne jest umiejętne wykorzystanie własnych kompetencji społecznych. Przystosowanie do sytuacji trudnych jest warunkiem prawidłowego funkcjonowania psychospołecznego. Poprawa jakości relacji interpersonalnych, decyduje o dobrej komunikacji, poznawaniu innych, wywieraniu na nich wpływów, ale również niesieniu wsparcia. Wyniki badań potwierdzają, że świadomość posiadania wysokiego poziomu kompetencji społecznych spełniafunkcję swoistego bufora wypalenia zawodowego i towarzyszących mu negatywnych elementów postaw, które przejawiają się w sferze behawioralnej, emocjonalno-motywacyjnej czy poznawczej (Smółka 2008; Nitsuma i in. 2012, s. 659-667).

Żuralska Żuralska R., Majkowicz M., Gaworska-Krzemińska (2012) wykazali, że wykształcenie nie ma wpływu na stosowany styl radzenia sobie ze stresem. W badaniach własnych potwierdzono ową prawidłowość. W konfrontacji z trudnymi sytuacjami pielęgniarki pediatryczne stosowały konstruktywne sposoby radzenia sobie ze stresem, które polegały na podejmowaniu wysiłków zmierzających do rozwiązania problemu przez poznawcze przekształcenia lub próby zmiany sytuacji (Żuralska i in. 2012).

Badania własne wskazują, że pielęgniarki i pielęgniarze przyjmują w sytuacjach problemowych pozytywne nastawienie, które sygnalizuje i skutkuje rozwiązywaniem problemów. Stwierdzono, że wiek i staż pracy wpływają istotnie na sposób radzenia sobie ze stresem. Im młodsza jest badana osoba, tym silniejszy styl emocjonalny, im starsza - tym słabszy. Dłuższy staż pracy w zawodzie pielęgniarskim wiąże się ze stosowaniem bardziej aktywnej postawy w przypadku pojawienia się trudności. Osoby z większym doświadczeniem zawodowym nabywają umiejętności dostosowania działań zaradczych do konkretnej sytuacji problemowej (Tartas i in. 2009). 
Badania własne wskazują, że wiek respondentów koreluje z rozwiązywaniem problemów i szukaniem wsparcia, podobnie jak i w badaniach Sygit (2009). Staż pracy respondentów dłuższy niż 20 lat decyduje o przyjęciu aktywnej postawy wobec problemów. Badania Tartas i wsp. (2009) wskazują, że pielęgniarki poniżej 40. roku życia częściej stosowały style radzenia sobie skoncentrowane na problemie i zachowania unikowe, co sprzyjało radzeniu sobie ze stresem. Po 40. roku życia wzrastała natomiast tendencja do przyjmowania strategii zwrot ku religii, co może świadczyć o poszukiwaniu wsparcia emocjonalnego. Zdaniem autorów wspomnianych badań granica wieku - 40 lat - wiąże się z występowaniem tak zwanego kryzysu środka kariery (Tartas i in. 2009). W badaniach własnych uzyskano wyniki wskazujące na korelacje wieku (powyżej 40. roku życia) z wyborem strategii radzenia sobie w sytuacjach trudnych przez rozwiązywanie problemu i szukaniu wsparcia. Basińska i Andruszkiewicz (2008) nie wykazały związku pomiędzy wiekiem respondentów a radzeniem sobie ze stresem. W badaniach Rodriguesa i Chavesa (2008) przeprowadzonych wśród 77 pielęgniarek oddziałów onkologicznych stwierdzono, że najczęstszym stosowanym sposobem radzenia sobie ze stresem było przeformułowanie, a następnie planowe rozwiązywanie problemów oraz kontrolowanie emocji, podczas gdy w najmniejszym stopniu stosowano akceptację odpowiedzialności. Badania Guido i wsp. (2011) przeprowadzone na grupie 143 pielęgniarek oddziałów szpitalnych wykazały nieco odmienne wyniki: głównym sposobem radzenia sobie w sytuacjach problemowych było planowe rozwiązywanie problemów, najrzadszym - konfrontacja.

Pojawienie się sytuacji stresowej powoduje silne napięcie emocjonalne i jest zależne od indywidualnej odporności psychicznej i emocjonalnej (Terelak 2001). Badania przeprowadzone przez Nyklewicz i Krajewską-Kułak (2008) z udziałem czynnych zawodowo licencjonowanych pielęgniarek i studentów pielęgniarstwa II stopnia, wskazują na deficyt umiejętności w radzeniu sobie w sytuacjach trudnych przy występowaniu silnych negatywnych emocji podczas rozmyślania o śmierci. Głównym stosowanym mechanizmem radzenia sobie jest ich tłumienie. Autorki badań dowodzą, że ma to negatywny wpływ na funkcjonowanie psychospołeczne, ponieważ wzrost napięcia emocjonalnego pogarsza stan zdrowia. Zdaniem OgińskiejBulik (2005) zwiększenie zdolności empatycznych wśród osób świadczących opiekę powoduje efektywniejsze radzenie sobie z własnymi uczuciami, zmniejsza poziom stresu oraz utrzymuje dobry stan zdrowia. W badaniach własnych najczęstszą formą radzenia sobie była koncentracja na problemie. Strategię tę stosują osoby potrafiące kontrolować sytuację oraz własne emocje. Uren i Graham (2013) podają, że nieefektywne sposoby radzenia sobie zwiększają stres, co wpływa istotnie na personel medyczny oraz jego umiejętności zawodowe. 
Zdaniem Łobody (1990) i Ratajczaka (1994) wysokie natężenie sytuacji stresowych $\mathrm{w}$ pracy może powodować obniżenie zadowolenia $\mathrm{z}$ życia osobistego i zawodowego, zmniejszenie zaangażowania w pracę, a w konsekwencji zaburzenia zdrowia somatycznego i psychicznego. Badacze stwierdzili, że dobre relacje w grupie pracowniczej są najważniejszym warunkiem zdrowia jednostki i dobrego funkcjonowania zespołu. Analiza wyników własnych wskazuje, że pielęgniarki w zakresie radzenia sobie ze stresem najczęściej przyjmują strategię aktywnego działania, polegającą na zmniejszeniu działania siły stresora, jakim jest praca. Drugą najczęściej stosowaną strategią zaradczą jest planowanie, które polega na ocenie stresora i próbie analizy, w jaki sposób można sobie z nim poradzić, wykorzystując nie tylko własne możliwości, ale i wsparcie interpersonalne. Powyższe wyniki są zbliżone do wyników badań Jachimowicz-Wołoszynek, Jakubowskiej i Leźnickiej (2011), przeprowadzonych w grupie pielęgniarek zabiegowych. Badane osoby charakteryzowały się wysokim dążeniem do perfekcji, przyjmowaniem ofensywnych strategii rozwiązywania problemów, a także dość wysokim poczuciem wsparcia społecznego.

\section{WNIOSKI}

1. Umiejętności radzenia sobie $\mathrm{z}$ problemami $\mathrm{w}$ sytuacjach trudnych przez personel pielęgniarski są częściowo uwarunkowane socjodemograficznie. Istotne znaczenie mają posiadane zdolności interpersonalne w zakresie komunikacji społecznej oraz własne zasoby odpornościowe.

2. Należy rozszerzyć badania o determinanty dyspozycji osobowościowych personelu pielęgniarskiego $\mathrm{w}$ celu określenia ich wewnątrzosobowych zasobów psychospołecznych - poczucia koherencji, samooceny oraz wsparcia społecznego. Uzyskane informacje o predyspozycjach zawodowych mogą być przydatne w kształceniu i doskonaleniu zawodowym personelu pielęgniarskiego.

\section{LITERATURA}

Basińska M., Andruszkiewicz A., 2008, Poczucie koherencji jako predykator zdrowego funkcjonowania w pracy - badania pracowników socjalnych. W: H. Wrona-Polańska (red.), Zdrowie - stres - choroba w wymiarze psychologicznym. Kraków, Oficyna Wydawnicza Impuls.

Bielawska J., 2014, Interdyscyplinarny charakter pielegniarstwa. „Zeszyty Naukowe Państwowej Wyższej Szkoły Zawodowej im. Witelona w Legnicy",11(2). 
Buyuk E.T., Rizalar S., Güdek E., Güney Z., 2015, Evaluation of empathetic skills of nurses working in oncology units in Samsun. „International Journal Caring Sciences", Turkey, 8.

Frąckowiak A., 2010, Zagrożenia w pracy pielęgniarki środowiskowej. „Zeszyty Naukowe Wyższej Szkoły Zarządzania Ochroną Pracy w Katowicach”, 1(6).

Gaweł A., 2003, Obciążenie praca pielegniarek pracujących $w$ systemie zmianowym 12-godzinnym. „Pielęgniarstwo XXI wieku”, 3.

Guido L.A., Linch G.F.C, Pitthan L.O., Umann J., 2011, Stress, coping and health conditions of hospital nurses. „Revista da Escola de Enfermagem da USP”, 45.

Jachimowicz-Wołoszynek D., Jakubowska M., Leźnicka M., 2011. Analiza zachowań i przė̇yć związanych z praca na przykładzie pielęgniarek. „Problemy Higieny i Epidemiologii”, 92(4).

Juczyński Z., Ogińska-Bulik N., 2008, Osobowość, stres a zdrowie. Warszawa, Wydawnictwo Difin.

Kato T., 2014. Coping with interpersonal stress and psychological distress at work: comparison of hospital nurse and salespeople. „Journal of Psychology Research and Behavior Management", 7.

Kowalczuk K., Krajewska-Kułak E., Jankowiak B., Klimaszewska K., Rolka H., Kondzior D., Kowalewska B., 2008, Zagrożenia zawodowe pielegniarek, położnych i lekarzy w środowisku pracy. „Problemy Higieny i Epidemiologii”, 89(2).

Kuriata E., Felińczak A., Grzebiluch J., Szachniewicz M., 2011, Czynniki szkodliwe oraz obciążenie praca pielęgniarek zatrudnionych w szpitalu, część II. „Pielęgniarstwo i Zdrowie Publiczne", 1(3).

Kurowska K., Zuza-Witkowska A., 2011, Empatia a wypalenie zawodowe u pielegniarek onkologicznych. „Nowiny Lekarskie”, 80(4).

Lazarus R.S., Folkman S., 1984, Stress, appraisal and coping. New York, Springer Publishing Company.

Łoboda M., 1990, Czynniki stresogenne w organizacji. W: A. Biela (red.), Stres w pracy zawodowej. Wybrane zagadnienia. Lublin, Wydawnictwo KUL.

Marcysiak M., Dąbrowska O., Marcysiak M., 2014, Wypalenie zawodowe a radzenie sobie ze stresem pielegniarek. „Problemy Pielęgniarstwa”, 22(3).

Nitsuma M., Katsuki T., Sakuma Y., Sato C., 2012, The relationship between social skills and early resignation in Japanese novice nurses. "Journal of Nursing Management", 20(5).

Nyklewicz W., Krajewska-Kułak E., 2008, Śmierć a emocje pielęgniarek - doniesienie wstępne. „Problemy Pielęgniarstwa”, 16(3).

Ogińska-Bulik N., 2005, Emotional intelligence in the workplace: exploring its effects on occupational stress and health outcomes in human service workers. „International Journal of Occupational Medicine and Environmental Health", 18(2). 
Perek M., Kózka M., Twarduś K., 2007, Sytuacje trudne w pracy pielegniarek pediatrycznych i sposoby radzenia sobie z nimi. „Problemy Pielęgniarstwa”, 15(4).

Ratajczak Z., 1994, Wsparcie społeczne w środowisku pracy a stres i jego skutki zdrowotne. W: Z. Ratajczak (red.), Psychologiczna problematyka wsparcia społecznego i pomocy. Psychologiczne problemy funkcjonowania człowieka w sytuacji pracy. Katowice, „Prace Naukowe Uniwersytetu Śląskiego”, 11(20).

Rodrigues A.B., Chaves E.C., 2008, Stressing factors and coping strategies used by oncology nurses. „Revista Latino-Americana de Enfermagem”, 16.

Sęk H. (2005), Poznawcze i kompetencyjne uwarunkowania wypalenia w pracy z chorymi. „Postępy Psychiatrii i Neurologii”, 14(2).

Smółka, P., 2008, Kompetencje społeczne. Metody pomiaru i doskonalenia umiejętności interpersonalnych. Kraków, Wydawnictwo Wolters Kluwer S.A.

Strelau J., 2000, Temperament a stres: Temperament jako czynnik moderujacy stresory, stan i skutki stresu oraz radzenie sobie ze stresem. W: I. Heszen-Niejodek, Z. Ratajczak (red.), Człowiek w sytuacji stresu. Problemy teoretyczne i metodologiczne. Katowice, Wydawnictwo Uniwersytetu Śląskiego.

Sygit E., 2009, Długoletni staż zawodowy pielęgniarek - droga ku wypaleniu zawodowemu? „Roczniki Pomorskiej Akademii Medycznej w Szczecinie”, 55(2).

Tartas M., Derewicz G., Walkiewicz M., Budziński W., 2009, Źródła stresu zawodowego w pracy pielęgniarek zatrudnionych w oddziałach o dużym obciążeniu fizycznym i psychicznym. „Roczniki Akademii Medycznej w Gdańsku”, 39.

Terelak J., 2001, Psychologia stresu. Bydgoszcz, Oficyna Wydawnicza Branta.

Uren S.A, Graham T.M., 2013, Subjective experiences of coping among caregivers in palliative care. „Online Journal of Issues in Nursing”, 18(2).

Wrońska I., Krajewska-Kułak E., 2007, Wybrane zagadnienia z pielęgniarstwa europejskiego. Lublin, Wydawnictwo Czelej.

Żuralska R., Majkowicz M., Gaworska-Krzemińska A., 2012, Psychologiczna ocena stylów radzenia sobie ze stresem a cechy osobowości studentów pielegniarstwa i położnictwa Gdańskiego Uniwersytetu Medycznego. „Problemy Pielęgniarstwa”, 20(2).

\section{SOCIODEMOGRAPHIC DETERMINANTS OF COPING WITH DIFFICULT SITUATIONS} FOR NURSING STAFF

Abstract: The results of coping with problematic situations can be assessed by analyzing physiological responses, motor activities and emotional symptoms. The more effectively a person copes in a problematic situation, the better his/her psychosocial functioning. The adequacy of the selected coping profile affects the state of somatic and mental health. The most important 
feature of coping should be flexibility - adaptation to changing conditions. The aim of the study was to assess the sociodemographic factors conditioning coping with difficult situations by nursing staff. The study included an 81-member group of nurses. The original "certificate of origin" was used for the sociodemographic characteristics of the subjects studied and the Questionnaire for coping with problems (WCQ Lazarus and Folkman) was provided. The study showed that there is a relationship between dealing with difficult situations by nursing staff and the place of residence, age and professional experience. Individual strategies of coping with difficult situations by respondents do not correlate with gender and education. The respondents most often choose the coping profile described as a positive attitude. Concentration on the problem and a positive attitude have the greatest impact on the psychosocial functioning of the respondents. The skills of coping with problems in difficult situations by nursing staff are partially conditioned by sociodemographic analysis. Interpersonal skills in the field of social communication and immune resources are of great importance. It is necessary to extend the research with the determinants of personality dispositions of nursing staff in order to determine their intra-personal resources, psychosocial - sense of coherence, self-esteem and social support. Obtained information on occupational predispositions may be useful in vocational education and training of nursing staff.

Keywords: nursing staff, problematic situations, stress, coping 